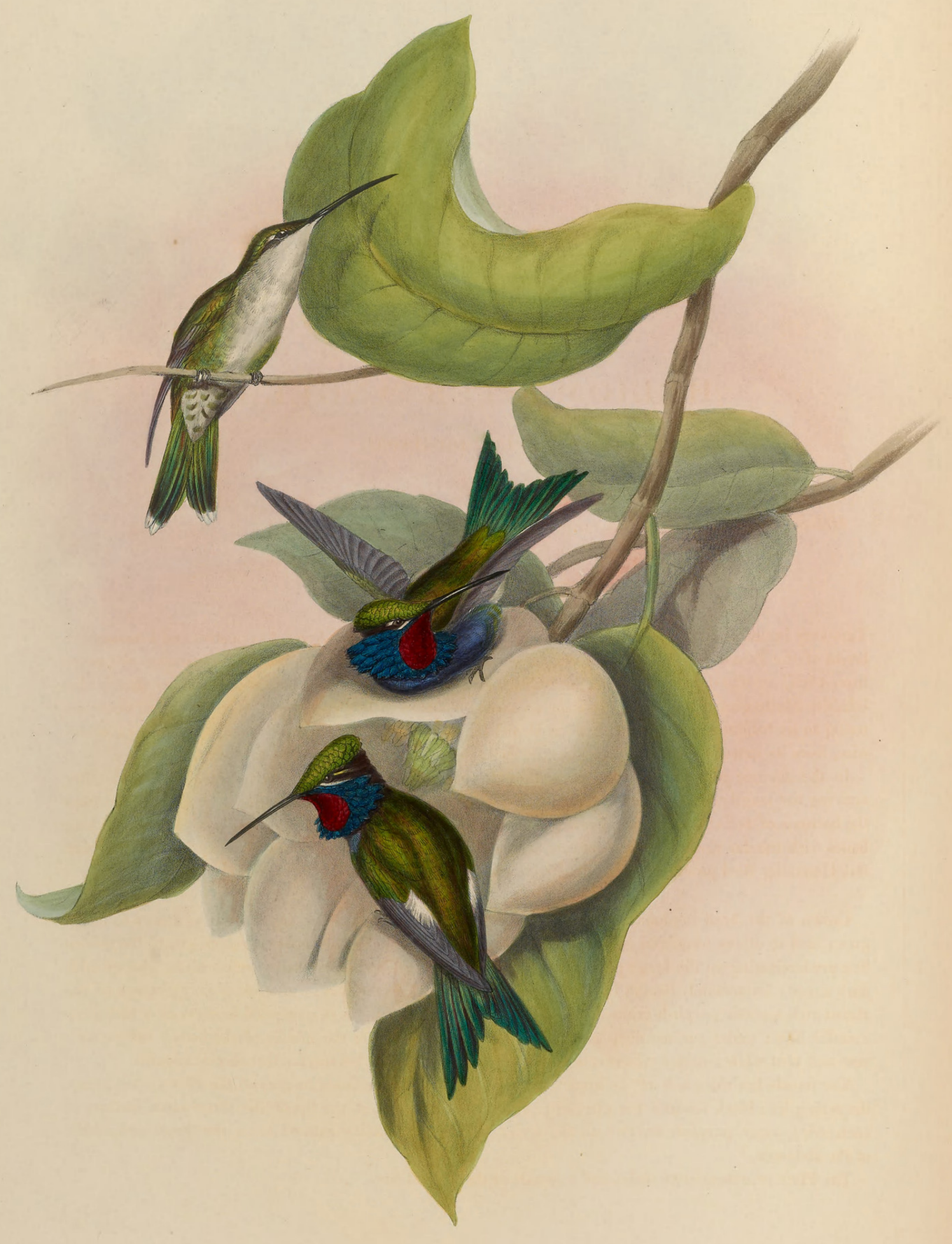

HETIOMASTER ANGEIAE 


\section{HELIOMASTER ANGELAE.}

\section{Angela Star-throat.}

Ornismya Angela, Less. Ill. de Zool., pl. 45.

Heliomaster angela, Bonap. Consp. Gen. Av., p. 70, Heliomaster, sp. 1.

THIs very beautiful Humming Bird ranges over the countries of Buenos Ayres, Corrientes, and I believe the banks of the Parana generally; it is from these countries alone that I have received specimens, and never from Chili, as stated by M. Lesson; in addition to these localities, Mr. Reeves informs me that it also inhabits Matto-grosso in Brazil. It is by no means common in our collections, a circumstance doubtless owing to its habitat not having been often visited by collectors from France or from this country; otherwise, from its extreme beauty and elegance, it could not have failed to attract their notice.

In the absence of all information respecting the habits and economy of this species, M. Lesson, after noticing the lengthened and slender form of the bill, remarks, that ordinarily it must obtain its food from the bottoms of bell-shaped flowers; and that it is from within the flowers of the Bignonias and of the long lianes with tubular corollas, which entwine and interlace each other in the forests of the New World, that this Humming Bird procures the small soft insects upon which it feeds.

Crown of the head luminous metallic green, changing in some lights to aquamarine, in others to bluish green, and in others to golden green ; all the upper surface and the wing-coverts golden green, the golden hue predominating on the lower part of the back; wings purplish brown; tail purplish black, glossed with dark green; immediately behind the eye a spot of white, and on the cheeks a streak of grey; centre of the throat rich metallic purplish crimson, on each side of which is a series of elongated feathers of a rich deep metallic blue; under surface deep green, passing into rich blue on the middle of the body ; tuft on each side and vent white; under tail-coverts green, fringed with white; bill black; feet blackish brown.

The female has the whole of the upper surface golden bronze, inclining to grey on the crown; tail green, deepening into black towards the extremity, and a spot of white at the tip of the three outer feathers of each side; wings purplish brown; all the under surface grey, fading into white on the throat and middle of the abdomen.

The Plate represents two males and a female of the natural size. 


\section{$2 \mathrm{BHL}$ Biodiversity Heritage Library}

Gould, John. 1859. "Heliomaster angelæ, Angela Star-throat. [PI. 263]." A monograph of the Trochilidae, or family of humming-birds 4, https://doi.org/10.5962/p.317072.

View This Item Online: https://www.biodiversitylibrary.org/item/108334

DOI: https://doi.org/10.5962/p.317072

Permalink: https://www.biodiversitylibrary.org/partpdf/317072

\section{Holding Institution}

Smithsonian Libraries

\section{Sponsored by}

Smithsonian Institution Libraries

\section{Copyright \& Reuse}

Copyright Status: NOT_IN_COPYRIGHT

This document was created from content at the Biodiversity Heritage Library, the world's largest open access digital library for biodiversity literature and archives. Visit BHL at https://www.biodiversitylibrary.org. 